\title{
Romanian Special Educators' Attitudes toward Students with Disabilities
}

\author{
Luminita Hartle, Ed.D. \\ Illinois State University \\ Campus Box 5330 \\ Normal, IL 61790, USA \\ MarkZablocki, Ph.D. \\ Illinois State University \\ Campus Box 5910 \\ Normal, IL 61790, USA \\ Sharon Doubet, Ph.D. \\ Illinois State University \\ Campus Box 5910 \\ Normal, IL 61790, USA \\ Amanda Quesenberry, Ph.D. \\ Illinois State University \\ Campus Box 5330 \\ Normal, IL 61790, USA
}

\begin{abstract}
This study examined the attitudes of Romanian special education teachers toward educating students with disabilities. Specifically, the study focused on revealing possible differences in teachers' attitudes based on their educational background and teaching experience. A total of 82 special educators were surveyed. The results showed that their attitudes toward students with disabilities varied. However, there was a slight difference between special educators with less experience and those who graduated from a pedagogical college, with college graduates having more positive attitudes. Participants also believed that students with disabilities can learn in general education settings when provided with appropriate supports.
\end{abstract}

Keywords: attitudes, special educators, students with disabilities

\section{Introduction}

The falling of the Romanian communist regime occurred in 1989. The transition towards a more democratic country had major implications on education, especially for children with disabilities (Ghergut, 2011). The Romanian Ministry of Education supported a series of initiatives to create a more inclusive and favorable approach for people with disabilities. However, limited school budgets and lack of educators' knowledge in the field of special education has slowed down the implementation initiatives related to social integration of children with disabilities (Bazgan \& Bazgan, 2015).Furthermore, another impediment towards increased integration was professionals and communities' negative attitudes toward people with disabilities. Various researchers have shown that professionals' attitudes have an impact on the type of educational services that students with disabilities receive in schools (Ghergut, 2011; Vrasmas \& Vrasmas, 2007). For example, when special educators have positive attitudes toward their students with disabilities, they are willing to provide a wider range of accommodations and support. In contrast, special educators who have negative attitudes toward students with disabilities tend to have lower academic expectations and less opportunities for involving the min extracurricular activities (Folostina, Duta, \& Pravalici, 2013; Unianu, 2012).

Similarly, Costea-Barlutiu \& Rusu (2015) found that there is a strong relationship between educators' training, experience, and attitudes. Therefore, special educators with more training and teaching experience with students with disabilities have positive attitudes toward this population. According with Unianu (2012), special educators' age and education may also influence their attitudes toward students with disabilities and toward their willingness to teach in inclusive settings. The type and severity of disability is another important factor that may influence professionals' 
attitudes. Gilmore, Campbell, and Cuskelly (2003) found that professionals tend to have more negative attitudes toward students with severe disabilities and students with challenging behaviors, especially regarding inclusion in general education classrooms.

Drugas (2015) found that negative attitudes toward these students can be a possible outcome of insufficient training. Therefore, in this study, we investigated the attitudes of Romanian special educators toward students with disabilities to learn more about the supports and services provided for students with disabilities.

\section{Method}

\section{Purpose}

Teachers of children with disabilities in Romania encounter many challenges due to a lack of appropriate training on how to meet their needs (Birta-Szkely, 2012). Considering the results of multiple studies conducted to examine this matter, it may be concluded that students with disabilities are usually excluded from the general education classrooms because teachers are unequipped to support them (Ghergut, 2012; Popa, Gliga, \& Michel, 2012; Unianu, 2013; Staiculescu \& Ungureanu, 2012). The purpose of the survey was to examine the attitudes of Romanian special educators and factors that may impact their attitudes toward children with disabilities.

\section{Research Questions}

1. What are the attitudes and perceptions of Romanian special educators toward students with disabilities?

2. Does the level of education and years of experience have an impact on special educators' attitudes toward students with disabilities?

\section{Participants}

The participants in the survey included 82 special education teachers. All of the participants worked directly with students with disabilities. A large majority (95\%) of the participants were female. Sixty percent of the participants completed a master's degree, thirty-two percent completed a university degree in special education or related area, and the remainder of the participants had a pedagogical degree. A pedagogical degree is a teaching degree where the educators can only teach children up to $4^{\text {th }}$ grade. More than half of the participants worked in the special schools and about $35 \%$ worked in private schools. More than $61 \%$ of the participants worked with students with intellectual disabilities and nearly $47 \%$ worked with students with ASD. Furthermore, $57 \%$ of the special educators worked with students who had only one type of disability, and $43 \%$ worked with students who have two or more types of disabilities. More information about the participants' demographic characteristics are summarized in Table 1.

Table 1. Survey Results: Demographic Information of Participants

\begin{tabular}{|c|c|c|}
\hline \multicolumn{3}{|l|}{ Characteristic } \\
\hline & $\mathrm{N}(82)$ & $\%$ \\
\hline \multicolumn{3}{|l|}{ Gender } \\
\hline Male & 4 & 4.9 \\
\hline Female & 78 & 95.1 \\
\hline \multicolumn{3}{|l|}{ Years of experience } \\
\hline Less than 5 years & 41 & 50.0 \\
\hline Between 6-10 years & 16 & 19.5 \\
\hline Between $11-20$ years & 12 & 14.6 \\
\hline More than 20 years & 13 & 15.9 \\
\hline \multicolumn{3}{|l|}{ Educational level completed } \\
\hline Pedagogical college & 6 & 7.3 \\
\hline University & 26 & 31.7 \\
\hline Some university level courses & 1 & 1.2 \\
\hline Master & 49 & 59.8 \\
\hline Doctoral & 0 & 0 \\
\hline \multicolumn{3}{|l|}{ Age group } \\
\hline Preschool (ages 3 and 4) & 11 & 13.4 \\
\hline Kindergarten (age 5) & 12 & 14.6 \\
\hline Elementary (grades $1^{\text {st }}-4^{\text {th }}$ ) & 35 & 42.7 \\
\hline Secondary (grades $5^{\text {th }}-8^{\text {th }}$ ) & 21 & 25.6 \\
\hline High School (grades $\left.9^{\text {th }}-12^{\text {th }}\right)$ & 3 & 3.7 \\
\hline \multicolumn{3}{|l|}{ Type of school } \\
\hline Private school & 4 & 4.9 \\
\hline
\end{tabular}


Public school

Special school

Institution

Setting for providing service

Pull-out program

General education classroom

Special education classroom

In and out of my classroom

One-on-one in the school

In inclusive classroom
28

44

6

2

7

36

7

16

14
34.1

53.7

7.3

2.4

8.5

43.9

8.5

19.5

17.1

\section{Data Collection Procedures}

To answer our research questions, the first author used an adapted survey originally developed by the Middle Level Leadership Center at the University of Missouri (2016). The survey included 12 open-ended questions related to special educators' attitudes and perceptions toward students with special needs, instructional practices, teaching methods, and assessment methods for students with special needs. The survey was administered in English and was piloted with three Romanian special educators prior to use for this study. The feedback received from piloting the surveys was minor; two teachers had no suggestions for improvements and one teacher suggested rephrasing some of the special education terms that are common in English but may not be familiar to Romanian special educators. The survey was conducted online using a university-sponsored survey platform. The survey included a Likert scale, open-ended, numerical, and multiple-choice questions. The Linkert scale included a scale from 1 to $5(1=$ strongly agree; and $5=$ strongly disagree $)$.

\section{Data Analysis}

The response rate for the survey was $82 \%$. For the survey analysis, the raw data was transferred from the online platform into Microsoft Excel. Data cleaning consisted of excluding incomplete surveys and identifying and correcting errors related to the survey responses to help minimize their impact on study analysis and results. The cleaned survey data were then exported from Excel into SPSS for coding. Once the data were exported to SPSS, the first author completed descriptive statistical analyses (mean, range, and standard deviation), reliability, and factor analysis across all variables in the study (Howell, 2010).

\section{Results}

\section{Attitudes and Beliefs toward students with disabilities}

Overall, we found that Romanian special educators' general attitudes and beliefs toward students with disabilities were varied (See Table 2). Teachers most agreed with the two survey statements that addressed perceptions of student competence $(M=1.93, S D=.84)$, and the efficacy of the general curriculum at their schools $(M=1.95, S D=.92)$. However, there were inconsistent responses concerning the inclusion of students with disabilities in the general education classroom. For example, responses were neutral when asked about the social and academic benefits of inclusion $(\mathrm{M}=2.68, \mathrm{SD}=1.3)$, and neutral when asked if students with disabilities learn best in special settings $(\mathrm{M}=$ $2.59, \mathrm{SD}=1.1)$.

Teachers generally agreed with the statement that students with disabilities have difficulty passing formal exams without appropriate accommodations and supports $(\mathrm{M}=2.07, \mathrm{SD}=0.77)$, and generally disagreed that students with disabilities are often absent or drop out of school $(\mathrm{M}=3.17, \mathrm{SD}=1.1)$. 
Table 2.Descriptive Statistics for Survey Items Related to Attitudes and Beliefs Toward Students with Disabilities

\begin{tabular}{|c|c|c|c|c|c|c|c|}
\hline \multirow[b]{2}{*}{$\begin{array}{l}\text { Survey } \\
\text { Item }\end{array}$} & \multicolumn{6}{|c|}{ Frequency and Percentage } & \multirow[b]{2}{*}{$\begin{array}{l}\text { Strongly } \\
\text { Disagree } \\
\text { (4) }\end{array}$} \\
\hline & $M$ & $S D$ & $\begin{array}{l}\text { Strongly } \\
\text { Agree } \\
\text { (1) }\end{array}$ & $\begin{array}{l}\text { Agree } \\
(2)\end{array}$ & $\begin{array}{l}\text { Neutral } \\
\text { (3) }\end{array}$ & $\begin{array}{l}\text { Disagree } \\
\text { (3) }\end{array}$ & \\
\hline $\begin{array}{l}\text { 1. Students with disabilities benefit } \\
\text { academically and socially when they are } \\
\text { in the same classroom with students } \\
\text { without disabilities. }\end{array}$ & 2.68 & 1.256 & $\begin{array}{l}18 \\
(22.0)\end{array}$ & $\begin{array}{l}22 \\
(26.8)\end{array}$ & $\begin{array}{l}15 \\
(18.3)\end{array}$ & $\begin{array}{l}22 \\
(26.8)\end{array}$ & $\begin{array}{l}5 \\
(6.1)\end{array}$ \\
\hline $\begin{array}{l}\text { 2. The general education curriculum, } \\
\text { when individualized promotes academic } \\
\text { growth and development for students with } \\
\text { disabilities. }\end{array}$ & 1.95 & .915 & $\begin{array}{l}25 \\
(30.5)\end{array}$ & $\begin{array}{l}45 \\
(54.9)\end{array}$ & $\begin{array}{l}5 \\
(6.1)\end{array}$ & $\begin{array}{l}5 \\
(6.1)\end{array}$ & $\begin{array}{l}2 \\
(2.4)\end{array}$ \\
\hline $\begin{array}{l}\text { 3. Students with disabilities can succeed } \\
\text { in school and can build a career or a } \\
\text { profession. }\end{array}$ & 1.93 & .843 & $\begin{array}{l}26 \\
(31.7)\end{array}$ & $\begin{array}{l}41 \\
(50.0)\end{array}$ & $\begin{array}{l}11 \\
(13.4)\end{array}$ & $\begin{array}{l}3 \\
(3.7)\end{array}$ & $\begin{array}{l}1 \\
(1.2)\end{array}$ \\
\hline $\begin{array}{l}\text { 4. Students with disabilities learn best } \\
\text { only in special settings (special education } \\
\text { classroom, or institutions). }\end{array}$ & 2.78 & 1.305 & $\begin{array}{l}16 \\
(19.5)\end{array}$ & $\begin{array}{l}14 \\
(17.1)\end{array}$ & $\begin{array}{l}24 \\
(29.3)\end{array}$ & $\begin{array}{l}22 \\
(26.8)\end{array}$ & $\begin{array}{l}6 \\
(7.3)\end{array}$ \\
\hline $\begin{array}{l}\text { 5. Students with disabilities require } \\
\text { additional time for planning and } \\
\text { instruction which is a disadvantage or } \\
\text { disservice for students without } \\
\text { disabilities. }\end{array}$ & 2.59 & 1.054 & $\begin{array}{l}13 \\
(15.9)\end{array}$ & $\begin{array}{l}28 \\
(34.1)\end{array}$ & $\begin{array}{l}23 \\
(28)\end{array}$ & $\begin{array}{l}16 \\
(19.5)\end{array}$ & $\begin{array}{l}2 \\
(2.4)\end{array}$ \\
\hline $\begin{array}{l}\text { 6. Students with disabilities are often } \\
\text { absent from school or drop-out of school. } \\
\text { 7. Students with disabilities have }\end{array}$ & 3.17 & 1.052 & $\begin{array}{l}6 \\
(7.3)\end{array}$ & $\begin{array}{l}13 \\
(15.9)\end{array}$ & $\begin{array}{l}32 \\
(39.0)\end{array}$ & $\begin{array}{l}23 \\
(28.0)\end{array}$ & $\begin{array}{l}8 \\
(9.8)\end{array}$ \\
\hline $\begin{array}{l}\text { difficulty passing formal exams and tests } \\
\text { without appropriate accommodations and } \\
\text { supports. }\end{array}$ & 2.07 & .766 & $\begin{array}{l}17 \\
(20.7)\end{array}$ & $\begin{array}{l}46 \\
(56.1)\end{array}$ & $\begin{array}{l}15 \\
(18.3)\end{array}$ & $\begin{array}{l}4 \\
(4.9)\end{array}$ & 0 \\
\hline
\end{tabular}

We were interested in exploring whether years of teaching experience was associated with different attitudes and beliefs. We created four categories of years of teaching experience that included a category for teachers with five years or less up to teachers with 20 years or more of experience (see Table 3). Overall, we found that teachers with fewer years of experience generally have more favorable perceptions and attitudes toward students with disabilities than teachers with more experience. For example, on the first three questions, fewer years of teaching experience were associated with more positive attitudes toward inclusion, student competence and the efficacy of the general education curriculum in their schools. Teachers with less than 5 years of experience were also more likely to disagree with the statement that students with disabilities learn best only in special settings and were more likely to disagree that the time spent planning and instructing students with disabilities was detrimental to students without disabilities. 
Table 3.Special Educators Self-Efficacy when Teaching Students with Disabilities

\begin{tabular}{|c|c|c|c|c|c|c|c|}
\hline \multirow[b]{2}{*}{$\begin{array}{l}\text { Survey } \\
\text { Item }\end{array}$} & \multicolumn{6}{|c|}{ Frequency and Percentage } & \multirow[b]{2}{*}{$\begin{array}{l}\text { Strongly } \\
\text { Disagree } \\
\text { (5) }\end{array}$} \\
\hline & $M$ & $S D$ & $\begin{array}{l}\text { Strongly } \\
\text { Agree } \\
\text { (1) }\end{array}$ & $\begin{array}{l}\text { Agree } \\
(2)\end{array}$ & $\begin{array}{l}\text { Neutral } \\
\text { (3) }\end{array}$ & $\begin{array}{l}\text { Disagree } \\
\text { (4) }\end{array}$ & \\
\hline $\begin{array}{l}\text { 1. I create various opportunities and } \\
\text { engaging activities for students with } \\
\text { disabilities to participate. }\end{array}$ & 1.49 & .633 & $\begin{array}{l}47 \\
(57.3)\end{array}$ & $\begin{array}{l}31 \\
(37.8)\end{array}$ & $\begin{array}{l}3 \\
(3.7)\end{array}$ & $\begin{array}{l}1 \\
(1.2)\end{array}$ & 0 \\
\hline $\begin{array}{l}\text { 2. I consciously select teaching } \\
\text { methods and activities to } \\
\text { accommodate students with } \\
\text { disabilities. }\end{array}$ & 1.49 & .724 & $\begin{array}{l}51 \\
(62.2)\end{array}$ & $\begin{array}{l}24 \\
(29.3)\end{array}$ & $\begin{array}{l}5 \\
(6.1)\end{array}$ & $\begin{array}{l}2 \\
(2.4)\end{array}$ & 0 \\
\hline $\begin{array}{l}\text { 3. During the instruction, I monitor } \\
\text { students with disabilities to make } \\
\text { sure they understand the content and } \\
\text { make adjustments accordingly. }\end{array}$ & 1.51 & .707 & $\begin{array}{l}47 \\
(57.3)\end{array}$ & $\begin{array}{l}31 \\
(37.8)\end{array}$ & $\begin{array}{l}1 \\
(1.2)\end{array}$ & $\begin{array}{l}3 \\
(3.7)\end{array}$ & 0 \\
\hline $\begin{array}{l}\text { 4. During instruction I model, } \\
\text { encourage, and support social } \\
\text { interaction between students with } \\
\text { and without disabilities. }\end{array}$ & 1.43 & .667 & $\begin{array}{l}53 \\
(64.6)\end{array}$ & $\begin{array}{l}25 \\
(30.5)\end{array}$ & $\begin{array}{l}2 \\
(2.4)\end{array}$ & $\begin{array}{l}2 \\
(2.4)\end{array}$ & 0 \\
\hline $\begin{array}{l}\text { 5.I have the appropriate skills, } \\
\text { knowledge, and training necessary } \\
\text { to work with students with } \\
\text { disabilities. }\end{array}$ & 1.51 & .741 & $\begin{array}{l}48 \\
(58.5)\end{array}$ & $\begin{array}{l}29 \\
(35.4)\end{array}$ & $\begin{array}{l}3 \\
(3.7)\end{array}$ & $\begin{array}{l}1 \\
(1.2)\end{array}$ & $\begin{array}{l}1 \\
(1.2)\end{array}$ \\
\hline
\end{tabular}

\section{Special Educators Self-Efficacy when Teaching Students with Disabilities}

Our second research question explored the attitudes and beliefs of teachers toward teaching students with disabilities. This construct is slightly different than the first question where we wanted to examine teachers' approaches to teaching students, above and beyond their general attitudes and perceptions.

Overall teachers had positive attitudes about their pedagogical approaches (see Table 4). A large majority of respondents either strongly agreed or agreed with all five response items on the survey $(95 \%, 97 \%, 95 \%, 95 \%, \& 94 \%$ respectively).

The five survey items included questions related to various opportunities to engage students with disabilities, selecting teaching activities to meet the needs of all learners, and the type of accommodating strategies provided to include students with various needs. We were also interested in exploring whether years of teaching experience was associated with different attitudes and beliefs toward working with students with disabilities. Data revealed no significant differences by years of experience. However, there were slightly more teachers with the most experience (11-20 years and $>20$ years) who agreed or strongly agreed with all five response survey items. 


\section{Table: 4. Descriptive Statistics for Survey Items Related to Attitudes and Beliefs Toward Students with Disabilities}

Frequencies

Survey

Item

\section{Less than \\ 5 years}

\section{Between}

6-10 years

\section{Between}

11-20 years
More than

20 years

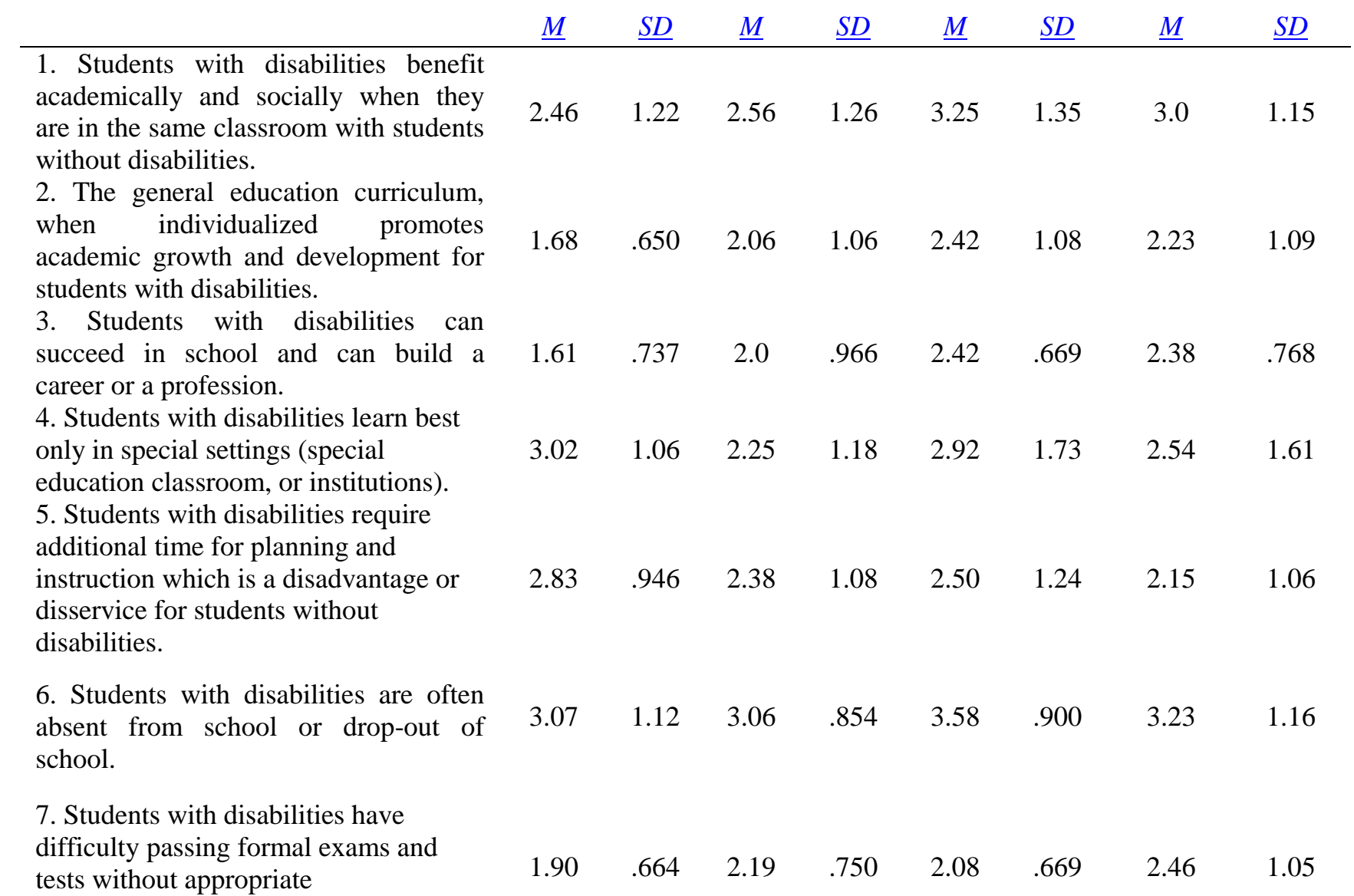

accommodations and supports.

Next, we examined the attitudes and beliefs of teachers based on their educational background (Table 5). Overall, we found that teachers who studied at a pedagogical college expressed more positive attitudes toward inclusion, student efficacy and the efficacy of the general education curriculum in their schools. These same teachersdisagreed most strongly with the statements related to students with disabilities learning best in self-contained classrooms, and that planning time for students with disabilities was detrimental to their non-disabled peers. Teachers who studied at University most stronglydisagreed that students learn best when included with their non-disabled peers. Across all groups there were consistent perceptions as to the attendance and dropout behaviors of students with disabilities $(\mathrm{M}=$ 3.0-3.5). 
Table: 5. Special Educators Self-Efficacy when Teaching Students with Disabilities

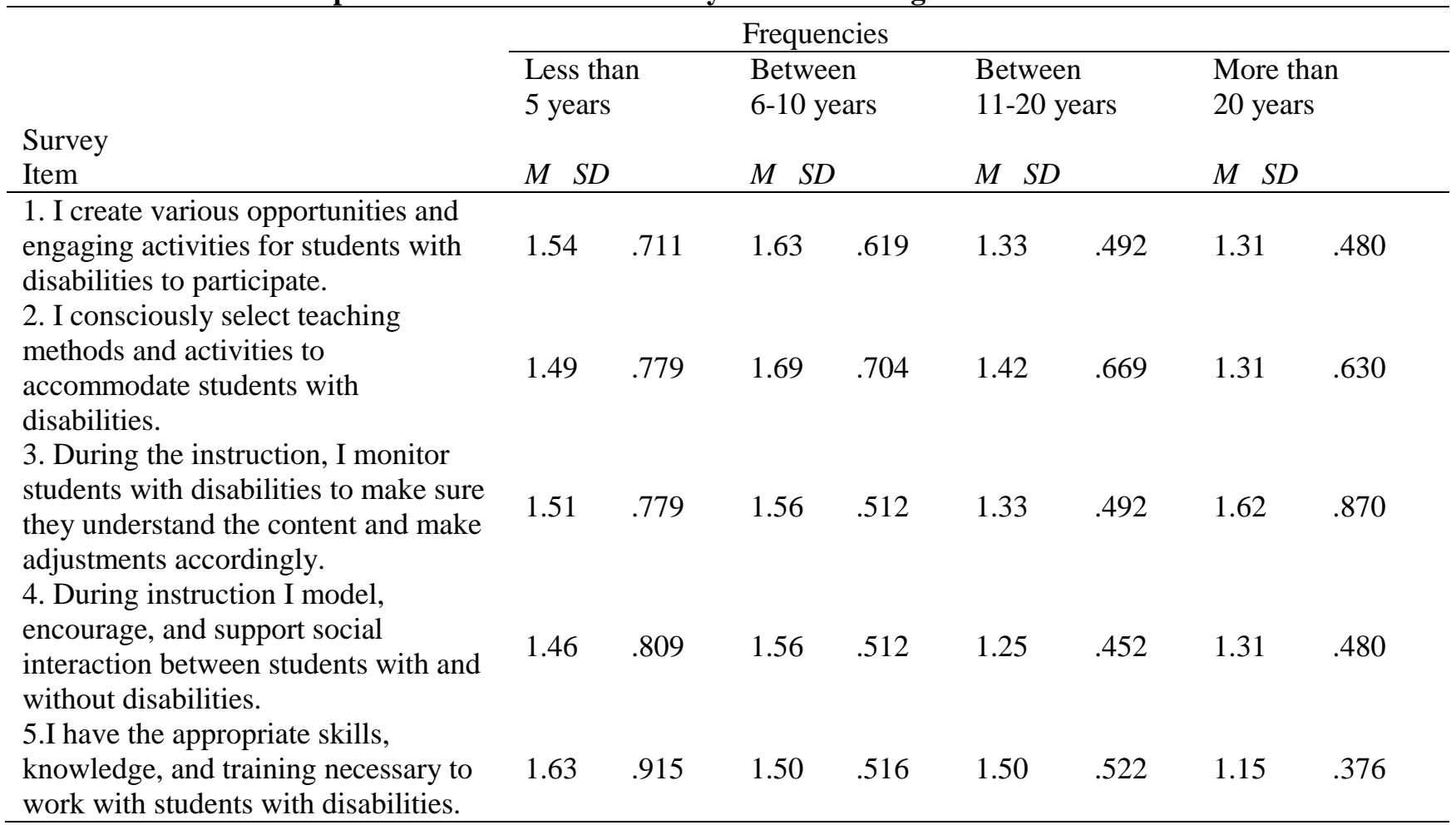

\section{Discussion}

In this study, we found that the successful integration of students with disabilities is often based on educators' understanding of inclusion and their attitudes toward working with students with disabilities regardless of the students' social, economic, or educational background. Furthermore, the concept of integration or inclusion does not only imply the physical integration of students with disabilities in general education classrooms, but also the type of teaching methods special educators use to support students with disabilities. Special educators have a critical role in supporting students with disabilities because they are expected to have the skills and abilities to support the needs of every child with a disability, regardless the setting in which they learn (Unianu, 2013; Ives, Runceanu,\& Cheney, 2007).

The findings of the current study show special educators' beliefs and self-efficacy about students with disabilities were mixed: half of the survey participants reported that students with disabilities benefit socially when included in general education classrooms and half of them disagreed with this statement. Furthermore, the participants reported that students with disabilities can be effectively included in general education classrooms when general education teachers provide adequate supports and services. Special educators from the current study strongly believed that students with disabilities have the academic abilities needed to succeed, but the current Romanian education system does not provide enough supports, and thus educators cannot meet the educational needs of all students with disabilities. Therefore, many families of students with disabilities choose special schools (special education students only) because they receive better academic services, even though they are less inclusive (Popa, Gliga, \& Michael, 2012). Other students with disabilities often leave general education classrooms because they fall behind, and public schools have limited to no funds to monitor and support students with disabilities (Povian \& Dumitrescu, 2015).

The previous studies conducted in Romania related to special education did not focus only on special educators. All the previous studies included educators from a variety of teaching specialties, including general education, therefore their attitudes toward students with disabilities varied. The findings from the current study are similar to other studies conducted in Romania (Drugas, 2012; Folostina, Duta, \&Pravalici, 2013; Ghergut, 2010; Ives, Runceanu, \& Cheney, 2007). For example,Drugas analyzed general education teachers' perceptions about including studentswith disabilities in general education classrooms. Drugas recruited 60 participants from mainstream schools (kindergarten, primary, and secondary levels). Out of sixty respondents, fifty-two had students with disabilities in their classroom. The participants' education level from this Drugas's studywas similar with the participants' education level from the current study. In the current study, $60 \%$ had a master's degree and $32 \%$ had a college degree, and $8 \%$ completed a pedagogical high school. 
The findings from the Drugas' study were similar to the findings of the current study ${ }_{2}$ in that the findings from the current study revealed that even though most special educators $(60 \%)$ have a master's degree, they lack the confidence and knowledge needed to work with students with disabilities.

In the current study, special educators who completed a pedagogical degree had slightly more positive attitudes toward students with disabilities than special educators who completed a university degree. Similarly, Birta-Szkely (2012)found that the best specialized instruction for educators who teach students with disabilities is provided only in special education departments in universities. Although many universities provide a wealth of courses about students with disabilities, the content may not be focused on best teaching practices for these students. Additionally, the amount of practical experiences gained from universities is less when compared with the practical experience received in special education teacher preparation programs and pedagogical degrees. Even though, pedagogical degrees prepare teachers to work with children from preschool to 4th grade and the program is limited to one optional course on working with children with special needs, the quality of instructionalcoursesis more intense and focuses on best teaching and assessment methods for young children with and without special needs(ANED, 2014; Ghergut,2010). In conclusion, the implications of teachers' skills, preparation, and self-efficacy need to be discussed at the school and university level.

\section{Limitations}

A few limitations should be considered when examining the findings of the current study. The recruitment criterion for the participants in the current study was limited. The findings about teachers' attitudes toward teaching and working with students with disabilities were gathered only from special educators. A larger and more diverse pool of participants is needed to examine whether teachers' attitudes differ based on their preparation, length of teaching experience, and if the participants teach in an urban versus a rural school.

\section{Recommendations and Conclusions}

A more in-depth and systematic investigation is needed to examine teacher preparation programs and the extent to which these programs may impact future educators' attitudes toward students with disabilities. Findings from the current study indicated that special educators have mixed attitudes toward students with disabilities. These findings were based on their training and level of understanding about the appropriate services needed to support students with disabilities.

Further investigation is needed to examine the content and the intensity of training that future educators receive regarding teaching students with disabilities in general or special education classrooms. Also, more complex studies of Romanian teacher preparation programs are needed to examine the curriculum and methodology used to train future educators to work with and teach students with disabilities. Furthermore, the number of students in class may be another important factor that could impact the quality of instructional practices and individualized activities for students with diverse needs.

Future researchers should also examine the importance of disability awareness and how it may impact educators' attitudes and abilities to support students and their families. Researchers should consider including parents of children without disabilities to understand their beliefs about disability and how special educators can help parents improve their perceptions of disability. It is important to examine if the parents allow their children to socialize or have friendships with children with disabilities and how these friendships may impact both groups of children. In conclusion, special education in Romania is relatively new; it is in the beginning stages of development. Now is the perfect time to examine and understand educators' attitudes and teaching strategies as a starting point for providing best services for special-needs students. The current study adds to the existing literature by reporting on Romanian special educators' attitudes towards students with disabilities. Its findings may support the efforts of educators and families in Romania as they strive to improve education opportunities for all students.

\section{References}

Bazgan, M., \&Bazgan, M. C. (2015). Special education needs: A Romanian approach. Journal Plus Education, 12, 713.

Birta-Szkely, N. (2012). Training teachers for inclusive education in Romania. School Psychology International, 33, 69-92.

Costea-Barlutiu, C., \&Rusu, A. (2015). A preliminary investigation of Romania university teachers' attitudes towards disabilities. A premise for inclusive interaction with students with disabilities. Procedia Social and Behavioral Sciences, 209, 572-579. 
Drugas, I.(2015). Teachers' perceptions about inclusive education and Attention Deficit Hyperactivity Disorder: Comparison between northwest and southwest Romanian teachers. Romanian Journal of School Psychology, $8(15), 50-61$.

Folostina, R., Duta, N., \&Pravalici, A. (2013). The attitudes of teachers toward integrating students with intellectual disability in regular schools in Romania. Social and Behavioral Sciences, 141, 505-511.

Ghergut, A. (2011). Education of children with special needs in Romania: Attitudes and experiences. Social and Behavioral Sciences, 12, 595-599.

Ghergut, A. (2012). Inclusive education versus special education on the Romanian educational system. Social and Behavioral Sciences, 46, 199-203.

Gliga, F., \& Popa, M. (2010). In Romania, parents of children with and without disabilities are in favor of inclusive education. Social and Behavioral Sciences, (2), 4468-4474.

Gilmore, L., Campbell, J. \&Cuskelly, M. (2003) 'Developmental expectations, personality stereotypes, and attitudes towards inclusive education: Community and teacher views of Down syndrome.' International Journal of Disability, Development and Education, 50(1), pp. 65-76.

Howell, D. C. (2010). Statistical methods for psychology (7th ed.). London, UK: Cengage Learning.

Ives, B., Runceanu, L., \& Cheney, C. (2007). Special education in Romania: Past, present, and future tensions. Journal of International Special Needs Education, 10, 5-12.

Popa, M., Gliga, F., \& Michel, T. (2012). The perceptions of parents on the issue of early intervention in child development. Social and Behavioral Science, 33, 303-307.

Povian, C. M., \&Dumitrescu, C. (2015). Educational system for children in need from Romania - in the Communist period and nowadays. Social and Behavioral Sciences, 197, 460-465.

Staiculescu, C., \&Ungureanau, M. (2012). The social inclusion of the children and young people with disabilities between desideratum and reality. Revista de Asistenta Sociala [Social Work Review], 11(2), 191-206.

Unianu, E. M. (2012). Teachers' attitudes towards inclusive education. Social and Behavioral Sciences, 33, 900-904.

Unianu, E. M. (2013). Teachers' perceptions, knowledge and behavior in inclusive education. Social and Behavioral Sciences, 84, 1237-1242.

Vrasmas, E., \&Vrasmas, T. (2007, August). Inclusive education in Romania. Regional preparatory workshop on inclusive education in Eastern and South Eastern Europe. Paper presented at the meeting of the International Bureau of Education, Sinaia, Romania. 